Murray CRG, Pitsillidou L, Caine C.

Student-led law reviews: What every UK law school needs?

The Law Teacher (2016)

DOI: http://dx.doi.org/10.1080/03069400.2016.1147309

\section{Copyright:}

This is an Accepted Manuscript of an article published by Taylor \& Francis in The Law Teacher on 17/03/2016, available online: http://dx.doi.org/10.1080/03069400.2016.1147309.

Date deposited:

$27 / 04 / 2016$

Embargo release date:

17 September 2017

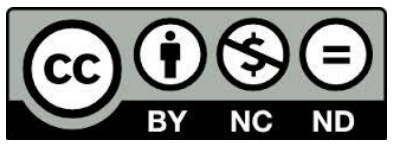

This work is licensed under a

Creative Commons Attribution-NonCommercial-NoDerivatives 4.0 International licence 


\title{
Student-led Law Reviews - What Every UK Law School Needs?
}

\author{
C. Caine, C.R.G. Murray and L. Pitsillidou*
}

\section{Key Words}

Law Reviews - US Legal Education - UK Legal Education - Coursework Assessment

\begin{abstract}
In the United States (US) student-run law reviews have long offered students the opportunity to develop their skills as editors and members of a publication team and to engage with new legal research. With law ordinarily taught as a three-year postgraduate degree, these reviews are normally staffed by a postgraduate editorial team. Similar efforts in the United Kingdom (UK) have largely been short-lived. Some venerable academic journals, such as the Cambridge Law Journal, started their lives as student-centred projects, but academics soon assumed control of the process due to the variable quality of undergraduate editing. This false start proved difficult to recover from, but a spate newly-founded student law reviews in the last decade suggests that these publications have increasing traction in UK legal education. This article evaluates the challenges and potential benefits of these efforts to translate US practice into UK law schools in light of the experience of creating and maintaining the North East Law Review, a student-led periodical based at Newcastle University which publishes student-generated content based on high-quality coursework submissions. This process potentially enhances the assessment process, with the student editorial team preparing essays for publication and student authors reengaging with their work in light of feedback. Publishing such essays furthermore allows all students to benchmark their own work against excellent coursework performance.
\end{abstract}

\footnotetext{
"Teaching Assistant, Senior Lecturer and Teaching Fellow, Newcastle Law School. The North East Law Review project upon which this research is based was generously funded by a Higher Education Academy (HEA) Teaching Development Grant (GENTDG133) and is available at: http://research.ncl.ac.uk/nelr/. Our thanks to Kevin Crosby (Newcastle) and Vicky Conway (Kent) for their encouragement and comments upon earlier drafts of this article. Any errors remain our own.
} 


\section{Introduction}

In the US student-edited law reviews are a prominent feature within legal education and 'serve as the primary vehicle for dissemination of legal scholarship'. ${ }^{1}$ Their benefits extend across students, staff and the reviews' parent institutions:

Law reviews ... provide outlets for academic thought for faculty; they provide an avenue for the development of the law; they affect legislation and judging; they serve as reference material; they permit the profession and academy to question orthodoxy; they provide student training; they serve as a vital credential for students and law faculty; they are the heritage of legal education and modern legal thought. ${ }^{2}$

Their century-long history has, in other words, burdened US law reviews with goals as diverse as enhancing the learning experience of students, contributing to academic discourse upon the law, advancing their parent law schools' research, marketing and recruitment strategies and providing a critical review of the legal order. The established nature of the US law review, however, contrasts with the absence of similar publications in the UK. Or, at least, it did. In recent years a wave of UK publications student-edited periodicals, explicitly influenced by North American publications, have been created. In some instances inaugural editions name-check the touchstone Harvard Law Review, ${ }^{3}$ whereas in others the founding editors were international students importing their cultural and personal experience of such publications. ${ }^{4}$ In this article we consider whether UK law schools will, like their US counterparts, come to need their own law review project.

The delayed emergence of UK student-edited law reviews can largely be explained by the predominance of the undergraduate law degree in UK legal education. This US, by contrast, maintains a model of postgraduate legal education with the intention that students begin their time at law school with 'a broad liberal education and a great level of maturity'. 5 As a consequence, UK law students have long been assumed not to have the same capacity to

\footnotetext{
${ }^{1}$ J.M. Donovan, C.A. Watson \& C. Osborne, 'The Open Access Advantage for American Law Reviews' Edison 2015-03A 1, p.2.

${ }^{2}$ C.C. Day, 'The Case for Professionally Edited Law Reviews' (2007) 33 Ohio NULR 563, p.563. See also R.A. Danner, 'Electronic Publication of Legal Scholarship: New Issues and New Models' (2002) 52 JLE 347, p.347.

${ }^{3}$ See L. Bain, 'Introduction to Volume Two' (2011) 2 Aberdeen SLR 7, p.7.

${ }^{4}$ See M. Kneic, 'Preface from the Editor-in-Chief' (2012) 1 MRLCE xi, p.xi and N. Lee, 'Foreword' (2011) 1 Southampton SLR i, p.i.

${ }^{5}$ S.R. Klein, 'Legal Education in the United States and England: A Comparative Analysis' (1991) 13 Loy LA Int'l \& Comp L Rev 601, p.635.
} 
manage a law review as their US counterparts. Moreover, the primacy of the peer-review model within UK legal academia has left little room for publications in which academic content is curated by students. We evaluate how this context has shaped the role and operation of the new UK law reviews, distancing them from their US cousins. In the US teams of student editors select and edit academic content for publication. We describe this model as the student-run law review. In the UK, by contrast, many recently-founded student law reviews involve student editors preparing for publication student content pre-selected by academics. We describe this model as the student-led law review. The number of new publications emerging under this model indicates a growing recognition of their value as educational tools within UK law schools.

We conduct this research in light of our experience, as student editors and staff liaison, of the workings of a case-study publication, the North East Law Review (NELR), founded at Newcastle University in 2013 and operated under the student-led model. The NELR's publication was an exercise in action research, being a collaborative staff-student project directed towards developing legal writing and research skills across Newcastle's undergraduate and postgraduate cohorts. ${ }^{6}$ In doing so, the NELR was intended to deliver the pedagogic benefits historically associated with US student-run law reviews whilst addressing or negating some of the problems which have affected this model. In common with other student-led law reviews, this approach has hitherto accepted a limited role for the NELR within academic discourse on law. Nonetheless, in the final section of this article we suggest that student-led publications could yet establish a place within mainstream UK legalacademic discourse if they partner student administration with peer review processes for academic submissions and channel student-generated content towards forms of academic writing, including case notes and book reviews, which have been disincentivised under the Research Excellence Framework (REF) arrangements.

\section{The Rise of US Student-Run Law Reviews}

Before exploring the place of student-edited law reviews within UK legal education, we must first cross the Atlantic to excavate the origins of these publications. Today, in spite of persistent criticisms (which we will examine in our next section), student-run law reviews

\footnotetext{
${ }^{6}$ Ortrun Zuber-Skerritt describes action research as 'collaborative, critical enquiry by the academics themselves (rather than expert educational researchers) into their own teaching practice, into problems of student learning and into curriculum problems'; O. Zuber-Skerritt, Action Research in Higher Education: Examples and Reflections (Kogan Page, 1992) pp.1-2.
} 
remain a thriving feature of almost all US Law Schools. Notwithstanding the mythology surrounding his Presidency of the Harvard Law Review, ${ }^{7}$ President Obama is just one of many successful US law graduates whose student years were shaped by their involvement in running a law review. ${ }^{8}$

Despite its global reputation, the Harvard Law Review was not the first student-run law review in North America. ${ }^{9}$ The publication, in 1875, of the Albany Law School Journal predated Harvard's periodical by over a decade and marked the beginning of this new departure in legal education. The Albany Journal, however, folded within a year. ${ }^{10}$ Although little more than an 'early skirmish' in student publishing, ${ }^{11}$ this experience highlighted the difficulty with sustaining student interest in a law review. Soon after, students at Columbia Law School published the Columbia Jurist. ${ }^{12}$ The student editors opened their inaugural volume with a striking assertion:

For the first time since the establishment of the Law School, a journal will supply a want long felt. The other departments of this College are each supplied with a paper or publication. Why are not we? Let each member of the Law School contribute heartily with pen and purse, and we believe that he will have no reason to regret his support to this enterprise. $^{13}$

The Jurist was intended to support law students at Columbia, promising to "publish every week the Moot Court Case, the decision of the Judge in full, and a complete list of the cases cited' ${ }^{14}$ It would, however, last only three editions because of the 'inability of the new student editors to meet the grinding task of putting out a weekly publication'. ${ }^{15}$ The early reviews faced a precarious existence until their remit could be honed to the point at which the required level of editorial commitment became compatible with legal study.

What differentiated the Harvard Law Review, first published in 1887, from its forerunners was in-part a highly-motivated student body 'taught to analyze' as opposed to

\footnotetext{
${ }^{7}$ B.H. Obama, Dreams from My Father (Canongate, 2007) pp.vii \& xiii.

${ }^{8}$ See F. Butterfield, 'First Black Elected to Head Harvard's Law Review' New York Times (6 Feb 1990).

${ }^{9}$ M.L. Swygert \& J.W. Bruce, 'The Historical Origins, Founding, and Early Development of Student-Edited Law Reviews' (1985) 36 Hastings LJ 739, p.763.

${ }^{10}$ Ibid., p.763.

${ }^{11}$ Ibid., p.765.

${ }^{12}$ Ibid., p.766.

${ }^{13}$ E. McCaskie, et al, 'The Columbia Jurist' (1885) 1 Colum Jurist 2, p.2.

${ }^{14}$ Ibid., p. 2.

15 supra n.9, p.768.
} 
memorise legal authorities through the new casebook method of teaching. ${ }^{16}$ But the initiallysecondary motivation behind the Review, of providing Harvard's faculty with 'a suitable organ of publication', ${ }^{17}$ was if anything more important to sustaining its existence, for it secured academic buy-in and provided the steady stream of high-quality content for students to edit (and alleviating the need for student editors to also generate much of the publication's content). ${ }^{18}$ The venture was closely supported by James Barr Ames, who continued to act as an advisor and mentor to the students running the Review throughout his tenure at Harvard. ${ }^{19}$ With such academic backing, and the boon of dramatic reductions in the cost of printing in the $1880 \mathrm{~s},{ }^{20}$ the Harvard Law Review established a successful model which was quickly replicated within other law schools. ${ }^{21}$ One hundred and forty years later, hundreds of US Law Reviews vie for attention and most law schools support multiple publications. ${ }^{22}$ Nonetheless, although the leading student-edited reviews remain amongst the most prestigious international outlets for legal writing, the US model has not escaped criticism.

\section{The Shortcomings of US Law Reviews}

Described by Dan Hunter as, 'a soft, slow-moving target for professorial browbeating, ${ }^{23}$ US law reviews have become the subject of sustained critique by academics and judges. ${ }^{24}$ Much of this critique relates to three alleged shortcomings, namely that student editors' poor decision making leads to biased and uninformed article selection, that the absence of academic peer review enables poor quality articles to circulate and that editorial overeagerness results in aggressive rewriting of manuscripts with an impact upon their coherence. These problems have generated a spectrum of responses, from proposals for wholesale reform of the US model, to fatalistic suggestions that law libraries should cancel subscriptions to student-run law reviews altogether. ${ }^{25}$

\footnotetext{
${ }^{16}$ Ibid., p.776.

${ }^{17}$ R. Zimmermann, 'Law Reviews: A Foray Through a Strange World' (1998) 47 Emory LJ 659, p.670.

${ }^{18}$ supra n.9, p.768.

${ }^{19}$ B.J. Hibbitts, 'Last Writes? Reassessing the Law Review in the Age of Cyberspace' (1996) 71 NYULRev 615, p.626.

${ }^{20}$ Ibid., p.620.

${ }^{21}$ J.W. Harper, 'Why Student-Run Law Reviews?' (1998) 82 Minnesota LRev 1261, p.1265.

${ }^{22}$ J. Doyle, 'The Law Reviews: Do their Paths of Glory Lead but to the Grave?' (2009) 10 JAPP 179, p.180.

${ }^{23}$ D. Hunter, 'Open Access to Infinite Content (Or "In Praise of Law Reviews")' (2006) 10 Lewis \& Clark LRev 761, p.763.

${ }^{24}$ This tradition dates to Fred Rodell's famous critique that in US law reviews, 'a pennyworth of content is most frequently concealed beneath a pound of so-called style'; F. Rodell, 'Goodbye to Law Reviews' (1936) 23 Virginia LRev 38, p.38.

${ }^{25}$ supra n.23, p.762.
} 
With regard to the first shortcoming, student inexperience has arguably led to articles being published based on the author's notoriety rather than its quality, ${ }^{26}$ and a bias towards legal topics and modes of analysis familiar to law students, with few student editors being equipped to evaluate non-doctrinal scholarship. ${ }^{27}$ When confronted with an article student editors find difficult to assess, Richard Posner contends that they often place misguided reliance upon proxies for merit such as the author's credentials or the length and number of footnotes in the article. ${ }^{28}$ Academic anxieties around this process are exacerbated by the absence of feedback for rejected articles (itself a function of the sheer volume of material handled by law reviews). ${ }^{29}$ The potential of such feedback for quality-enhancement is therefore lost. ${ }^{30}$

The second enduring criticism is that work published in law reviews will be of variable quality because it is not subject to peer review. Frances Olsen notes that the closest approximation to peer review currently employed in most US law reviews is the 'somewhat random practice of student editors seeking advice from their friendly professors'. ${ }^{31}$ The decision to seek an academic review and choice of reviewer are therefore functions of student experience. The way in which student editors select staff members to provide such assistance is questionable, bearing more relation to their perceived approachability than their specific expertise. In recent decades the eagerness of editorial teams to assert their independence from faculty has led to student editors increasingly relying upon their own judgement in circumstances when their forebears would have turned to academics for the 'counsel that we were clever enough to recognize (if not always admit) we needed'. ${ }^{32}$

Whilst praised, often faintly, ${ }^{33}$ for their generally careful citation-checking (a responsibility which most peer-reviewed journals place upon the author), student editors are frequently criticised for their tendency to over-edit content. This tendency towards aggressive editing applies even to manuscripts which are accepted for publication. Over-editing supposedly takes place because inexperienced student editor do not understand complicated material and redraft it in a way which mangles or neutralises the author's argument. Defensive practice consequently sets in, with academics devoting considerable attention to

\footnotetext{
${ }^{26}$ F. Olsen, 'The Role of Student-Run Journals in Opening North American Law' (2001) 39 Alberta Law Review 678, p.679.

${ }^{27}$ R.A. Posner, 'The Future of the Student-Edited Law Review' (1994) 47 Stan LRev 1131, p.1133.

${ }^{28}$ Ibid., p. 1134.

${ }^{29}$ supra n.19, p.645.

${ }^{30}$ supra $\mathrm{n} .27, \mathrm{p} .1134$.

${ }^{31}$ supra n.26, p.678.

32 J.G. Kester, 'Faculty Participation in the Student-Edited Law Review' (1986) 36 J Legal Educ 14, p.14.

${ }^{33}$ Ibid., p.1134.
} 
the explanation of basic concepts, particularly where an article pursues an interdisciplinary approach, lest it fall foul of student editors. ${ }^{34}$

For Posner, poor editing and poor selection are the hallmarks of the student-run model:

The situation is basically hopeless, though fortunately not serious. Hopeless because the problems reside in the unchangeable structure of the institution - the inherent inexperience and immaturity of student editors, the absence of the spur of competition, and the absence of continuity, which reduces the incentive to make changes since the fruits are unlikely to ripen in time to be harvested by the editors who initiate them. ${ }^{35}$

Many US legal academics do not share these concerns over student-run law reviews. Hunter, although by no means an advocate for the model, concludes that many of the complaints against law reviews result from the unwillingness of legal scholars to receive criticism of their work from students. ${ }^{36}$ Since law review editors have become the "primary gatekeepers and streamers of legal scholarship' in the US, ${ }^{37}$ a position without parallel in other countries and other disciplines, a backlash from disgruntled academics is all too predictable. In response to concerns that student editors are unable to distinguish what does and does not need editing, Hunter considers that US law reviews processes are in many respects similar to those of peer-refereed journals, with articles receiving multi-phase vetting through the exchange of drafts between the author and student editors. ${ }^{38}$ Student editing can in some instances enhance aspects of publications more than the peer-review model, for once the 'revise-and-resubmit' stage for peer-review journals has been completed, demands on journal resources and editorial time mean that proofreading and citation checking, which are standard features of the student-run model, are often neglected. ${ }^{39}$

Many of the weaknesses of US law reviews would dissipate if the element of student review of academic work was side-lined. ${ }^{40}$ Indeed, the push to make student editing as rigorous as possible generated complaints from the 1960s onwards that US-model reviews

\footnotetext{
34 supra n.19, p.648.

35 supra n.27, pp.1135-1136 .

${ }^{36}$ supra n.23, p.766.

${ }^{37}$ supra n. 19 , p.640.

38 supra n.23, p.765.

${ }^{39}$ Ibid., p.764.

${ }^{40}$ Some US law reviews have circumvented this approach by signing up to the Peer Reviewed Scholarship Marketplace. See R.A. Wise, et al, 'Do Law Reviews Need Reform? A Survey of Law Professors, Student Editors, Attorneys, and Judges’ (2013) 59 Loyola LRev 1, pp.73-74.
} 
were becoming elitist in their ethos. ${ }^{41}$ Involvement in law reviews came to be seen as a way for the best law students to burnish their résumés. ${ }^{42}$ In the late-twentieth century competition for places on editorial teams consequently became intense, leading to ever more stringent criteria for entry, such as editing tests and the preparation of sample casenotes. ${ }^{43}$ The upshot of these developments was to restrict the educational benefit of serving on a review to students who likely have the least need for such experience. Although efforts began in the 1970s to make editorial teams more reflective of the diverse student bodies attending US law schools, ${ }^{44}$ the level of commitment required of student editors continued to intensify. As one jaded former editor put it; '[n]ew law review members are like indentured servants: they are granted passage into the world of legal scholarship, but they pay for the privilege'. ${ }^{45}$ In leading law reviews the expansion in the volume of prospective articles outstripped the expansion in the size of law review teams as academics submitted every draft article to multiple reviews to maximise their chances of acceptance. ${ }^{46}$ Rather than being a beneficial addition to studies, multiple editors would recount how their degrees came to be neglected in satisfying their law review commitments. ${ }^{47}$ As early as the 1950 s calls began for US law reviews to shift their focus towards the publication of student work, beyond mere notes and comments, as a means of tackling some of these issues. ${ }^{48}$ Whilst in the US the student-run model was sufficiently entrenched to resist these calls, the UK remained uncharted territory for student-edited periodicals, opening up scope for a new model to emerge.

\section{The Poor Relations: The Stop-Start Emergence of UK Student Law Reviews}

For all their centrality to US legal education student-edited law reviews play little role in legal education in large parts of the world. Despite the common roots of the US and UK legal orders, the UK has been no exception in this regard. Several decades after the first studentrun US law reviews emerged, the Cambridge Law Journal was founded in 1921 by the young American Fellow at Corpus Christi College, Arthur Goodhart, alongside Henry Salt, a Trinity

\footnotetext{
${ }^{41}$ See J.D. Gordon III, 'How Not to Succeed in Law School' (1991) 100 Yale LJ 1679, p.1700.

${ }^{42}$ See J.C. Oleson, 'You Make Me [Sic]: Confessions of a Sadistic Law Review Editor' (2004) 37 UC Davis LRev 1135, p.1139.

${ }^{43}$ Ibid., pp.1137-1138.

44 supra n.19, pp.649-650.

45 supra n.42, p.1138.

${ }^{46}$ See L.M. Friedman, 'Law Reviews and Legal Scholarship: Some Comments' (1998) 75 Denver ULRev 661, p.664.

${ }^{47}$ supra n.19, p.646.

${ }^{48}$ H.C. Havighurst, 'Law Reviews and Legal Education' (1956) 51 NwULRev 22, pp.25-26.
} 
College undergraduate. ${ }^{49}$ Goodhart's import of US ideas was well timed, given the generation of First World War veterans, including Salt, ${ }^{50}$ reading law at Cambridge. The undergraduate body was therefore older and much more experienced than would ordinarily have been the case. In the first issue, having invoked the success of the Harvard Law Review, H.D. Hazeltine praised the student editorial input as 'a valuable training; and this work on the Journal is already viewed at Cambridge as one of the highest goals of student-ambition'. ${ }^{51}$ Prominent amongst the early undergraduate editors was Gerald Upjohn, future Lord of Appeal in Ordinary. ${ }^{52}$ But alongside the pedagogic justifications for establishing the new journal, Hazeltine also noted the value to legal scholarship; 'legal authorship by students of first-rate ability has a wider aspect, for [such] contributions ... possess a value for older lawyers in their work as teachers or as practitioners'. ${ }^{53}$ In Neil Duxbury's opinion a 'masteropportunist', Goodhart used his experience as a spring-board to the editorship of the Law Quarterly Review in $1926 .{ }^{54}$ Without his input, however, Cambridge's undergraduates soon relinquished editorial control to academic staff, ironically under Hazeltine's editorship. Looking back at the experiment in the 1960s, Goodhart diagnosed the level at which law is taught as the main reason for the failure of US-model law reviews to emerge in the UK:

[A]t all ... English Universities, law is taught primarily as an undergraduate subject to students who usually enter the University at the age of eighteen. It would not be reasonable to expect such youthful students ... to do the advanced and original work that is accomplished by the editors of the American university law journals. ${ }^{55}$

Despite this appraisal, the idea of a Cambridge-based student law review eventually resurfaced with the establishment of the Cambridge Student Law Review (Cambridge SLR) in 2003, this time publishing student-generated content edited by a team of undergraduates and postgraduates. Once again the experiment was brief, with the CSLR being replaced by the Cambridge Journal of International and Comparative Law (CJICL) in 2011, which was 'run by a young, up and coming team of doctoral candidates at the Law Faculty'. ${ }^{56}$ The

\footnotetext{
${ }^{49}$ See H.A. Hollond, 'Arthur Lehman Goodhart' (1964) 22 CLJ 1, p.1.

${ }^{50}$ See 'Foreigners Receive Various Awards' Harvard Crimson (8 Oct 1923).

${ }^{51}$ H.D. Hazeltine, 'Foreword' (1921) 1 CLJ 1, p.3.

52 See 'Editorial Board' (1926) 2 CLJ 365. Upjohn would even secure a contribution from his father, a barrister; W.H. Upjohn, 'Choice of Law' (1926) 2 CLJ 321.

53 supra n.51, p.3.

${ }^{54}$ N. Duxbury, Jurists and Judges: An Essay on Influence (Hart, 2001) p.89.

55 A.L. Goodhart, The Jubilee of the Iowa Law Review (1964) 50 Iowa LRev 1, p.3.

${ }^{56}$ A. Sanger \& R. Yotova, 'Editors' Introduction: "Continuity And Change"” (2012) 1 CJICL 2, p.2.
} 
change in title also marked a shift from student-generated content to double-blind peer review of academic work administered by the editorial team. ${ }^{57}$

The Cambridge SLR, although short-lived, was at the forefront of a new generation of student publications in the UK. Having a publication in which the students contributed the content, as well as editing and publishing it, demonstrated a distinct departure from the US model of students publishing academic work. This resurgence can be traced to the inaugural publication, in 1994, of the UCL Jurisprudence Review, which Stephen Guest intended to use as a vehicle for disseminating the best essays produced by each cohort of students on UCL's compulsory undergraduate jurisprudence module. ${ }^{58}$ Although this coursework was curated by academics on the jurisprudence teaching team, the staff took advantage of burgeoning word processing skills amongst the UCL student body when it came to preparing the content for publication. This involvement of the students kept costs down and permitted free distribution. ${ }^{59}$ For Guest, the creation of the Jurisprudence Review amounted to discovering 'an unmet need'. ${ }^{60}$ Looking back over the Review's first two decades, Paul Mitchell expressed the satisfaction of UCL staff that:

[E]ver-growing numbers of students at both undergraduate and postgraduate level are addressing challenging, important issues and producing excellent dissertations. Part of our aim is to give outstanding dissertations the wider audience they deserve. ${ }^{61}$

Student involvement expanded from a single over-worked editor to an editorial board, thereby 'sharing around the very valuable experience gained from doing this sort of work'. ${ }^{6}$

Although the Jurisprudence Review marked an important new departure for UK law reviews, it remained under Guest's guidance for much of its life, and not long after he stood down as staff editor in 2008 the publication was radically overhauled, becoming the UCL Journal of Law and Jurisprudence (UCLJLJ). In introducing the new publication, UCL's Head of School Hazel Genn noted that the dedication of the students performing editorial, production and marketing roles indicated that the long-standing resistance to student publishing in UK law schools had been misplaced; "we have not been making the most of the enormous energy, enthusiasm and commitment of law students to being involved in the

\footnotetext{
${ }^{57}$ Ibid., p.4.

${ }^{58}$ See A. Lewis, 'Introduction' (1995) 2 UCLJ Rev vi, p.vi.

${ }^{59}$ Ibid., p.viii.

${ }^{60}$ See S. Guest, 'Introduction' (1994) 1 UCLJ Rev ii, p.viii.

${ }^{61}$ P. Mitchell, 'The Origins and Aims of the Journal' (2012) 1 UCLJLJ vii, p.vii.

${ }^{62}$ Ibid., p.viii.
} 
dissemination of new ideas'. ${ }^{63}$ Nonetheless, although Genn renewed UCL's commitment to 'showcase some of the outstanding research being produced by students', ${ }^{64}$ this did not necessarily involve the publication of undergraduate work. The journal rapidly shifted towards attracting submissions by postgraduate students at UCL and other institutions. ${ }^{65}$ As with the Cambridge publications, undergraduate work was side lined, being absent from the second volume onwards, in favour of the double-blind peer review of a mixture of LLM dissertations and unsolicited contributions, administered by a student editorial team which was becoming the preserve of UCL's doctoral candidates. ${ }^{66}$

From these tentative beginnings it should be evident that there is, as yet, no dominant model for student-edited law reviews in the UK. The Durham Law Review (DLR) is an example of a student review that has followed the US model in publishing student-edited academic articles with the lofty goal of the advancement of legal debate amongst contemporary legal scholars' ${ }^{67}$ Previously known as Inter Alia, it was founded in 1992 but has had a chequered history, being inactive for extended periods and is currently moribund. Part of the problem has been the difficulty of attracting academic contributions to a studentedited journal given the culture of peer review in UK legal academia. A very different approach was adopted by the Student Journal of Law, first published in 2011, and presenting itself as 'the only active national law journal written by students for students' ${ }^{68}$ As opposed to an editorial board, this publication recruits student representatives from various UK universities through its website, and publishes work from undergraduate and postgraduate students. This approach, not tethered to a particular parent institution, can be sustained in the short run due to the limited costs associated with online publishing, but will need to attract external sponsorship in the absence of institutional support if it is to continue to meet website, server and administration costs, and cannot draw upon the institutional loyalty of a fixed student body.

Building upon these beginnings a handful of institutional student publications have emerged in recent years, including the Aberdeen Student Law Review (Aberdeen SLR), Edinburgh Student Law Review (Edinburgh SLR), the Kent Student Law Review (Kent SLR) the King's Student Law Review (King's SLR), the Manchester Review of Law, Crime and

\footnotetext{
${ }^{63}$ H. Genn, 'Foreword' (2012) 1(1) UCLJLJ vi, p.vi.

${ }^{64}$ Ibid., p.vi.

${ }^{65}$ H. Genn, 'Foreword' (2013) 2 UCLJLJ vi, p.vi.

${ }^{66}$ H. Genn, 'Foreword' (2014) 3 UCLJLJ vi, p.vi.

${ }^{67}$ See M. Bate, 'President's Letter' (2005) 4 Inter Alia 33, p.33.

${ }^{68}$ See Student Journal of Law: Sponsorship, available at: http://www.sjol.co.uk/sponsorship (accessed 6 Oct 2015).
} 
Ethics (MRLCE), the Southampton Student Law Review (Southampton SLR), the University of Liverpool Law Review (ULLR) and the Warwick Student Law Review (Warwick SLR). These journals differ in the composition of their editorial teams, the nature of articles that they publish and their means for attracting submissions. They nonetheless share a reliance upon open-access formats, ${ }^{69}$ involve cooperation between the student editors and academics ${ }^{70}$ and derive the bulk of their content from undergraduate and postgraduate coursework and dissertations produced in their parent law schools. ${ }^{71}$ As we have seen, the student-run law review model took time to emerge in the US and after various false starts only flourished in the late-nineteenth century as new technology reduced production costs. Likewise this profusion of periodicals, taking advantage of the flexibility of online publication and dissemination through legal databases, could well herald the dawn of an era in which studentled law reviews become an integral feature of UK legal education.

\section{The NELR Case Study}

To provide a window into the operation of this new wave of UK student law reviews, and to highlight their distinctive attributes by comparison to US law reviews, we case study one of these publications, the NELR. The NELR is an open-access student-led journal established in January 2013 by an editorial board comprising of both undergraduate and postgraduate students from Newcastle Law School. ${ }^{72}$ The inaugural volume was launched in June 2013 by Lord Hope of Craighead. Annual volumes have followed, with Baroness Hale of Richmond launching the 2015 volume.

As with the traditional US model, the administration of the NELR by members of the student body keeps running costs to a minimum, but the first point of distinction is that the NELR is primarily an open-access digital publication, further reducing overheads. A small print run of each volume is produced primarily for distribution amongst the editorial team, published authors and sponsors. Costs associated with the NELR's publication are therefore

\footnotetext{
${ }^{69}$ The metaphor of the law review as a 'showcase' for the parent law school crops up regularly within forewords for law reviews by Heads of School. See, for example, G. Howells, 'Preface from the Head of the School of Law' (2012) 1 MRLCE vii, p.vii and supra n.4, p.i.

${ }^{70}$ This cooperation can take the form of staff acting as liaison or advisers, for examples of which, see supra n.3, p.7, H. Biggs, 'Foreword' (2012) 2 Southampton SLR i, p.i. Some student law reviews maintain a formal academic Advisory Board or Review Panel for assessing submissions/outputs, as explained in N. Mesiainen \& A. Tabrizi, 'Editorial' (2014) 1 Kent SLR 1, p.1 and V. Pun, 'Preface' (2015) 1 ULLR v, p.v.

${ }^{71}$ See, for example, D. Scullion, 'Introduction to Inaugural Issue' (2010) 1 ASLR 7, p.7 and C. Hawthorne, P. Tominey \& K. Wilson, 'Editorial' (2009) 1 Edinburgh SLR vii, p.vii.

${ }^{72}$ See http://research.ncl.ac.uk/nelr (accessed 18 Oct 2015).
} 
negligible. It can be accessed through a website hosted on institutional servers. The on-going cost of maintaining this website is therefore subsumed into the larger cost of the parent law school website. This approach to dissemination ensures that the NELR is available to the broadest possible readership. The publication is also available through the HeinOnline database, increasing the visibility of the NELR in the specific context of legal academic research and providing a back-up archive of material in the event that content is lost or publication ceases.

In a further contrast to the US model, by which law reviews tend to derive much of their content from submissions by legal academics (or by students into comments sections), the NELR primarily provides a platform for disseminating high-quality student coursework and dissertations. Criticisms of US law reviews relating to student exercises of academic judgement in the selection and editing process are thereby circumvented. Rather than student editors selecting content from work submitted to them by student contributors, the NELR's content is selected by the academic liaison from a pool of the best essays and dissertations produced in each honours-level undergraduate and taught-postgraduate module in the previous academic year. All essays selected must have attained a mark of 80 or better $^{73}$ to be considered for publication in the NELR. This approach eliminates the possibility of students selecting articles on the basis of non-academic factors, or making selections in the absence of subject-specific experience. This approach to the selection of content is not without some drawbacks. It prioritises the administrative efficiency of the system for quality assurance over the range of content, making the NELR's subject coverage dependent upon undergraduate and postgraduate modules which include an essay component. At Newcastle University, seven out of the twenty-seven undergraduate law modules running in the 2015/16 academic year do not include an essay component in their assessment. Nonetheless, the inclusion of dissertations as long articles offsets any consequent diminution in the publication's coverage. Other new-wave reviews have operated unsolicited submission processes, managing quality control through an academic review process. ${ }^{74}$ This approach to content selection requires more active engagement with the law review process by contributing students, but can lead to the publication of work by students who are sufficiently confident in their own abilities to

\footnotetext{
${ }^{73}$ At Newcastle Law School step marking in the first-class category applies set marks of 75, 80 and 85 (or better) to bare, solid and outstanding first-class work. The requirement that work must have attained a mark of 80 or better therefore means that academic markers must have made an unequivocal judgment as to its quality. This selection mechanism, however, does not circumvent many of the critiques of quality assurance in higher education assessment, for a summary of which see S. Bloxham, 'Marking and Moderation in the UK: False Assumptions and Wasted Resources' (2009) 34 A\&EHE 209.

${ }^{74}$ See J. Adams \& J. Manwaring, 'Foreword' (2013) 3 Warwick SLR i, p.i.
} 
submit their efforts to further scrutiny, and not the publication of the strongest essays produced by a cohort. Moreover, this approach requires an extra selection stage, drawing upon academic time or taxing the capabilities of inexperienced student editors. This stage adds little value to the quality assurance process where an already-assessed essay is under consideration.

Whereas US student-run law reviews vigorously assert their independence from faculty, the student-led approach relies upon a cooperative relationship between the academic staff who select material and the student editors who prepare it for publication. In many newwave reviews this cooperation extends to staff 'formally instructing student editors ... about the proper role of editors of scholarly journals' ${ }^{75}$ Training students from the beginning of their time on an editorial team enhances their skill and confidence as editors and improves the publication's quality. ${ }^{76} \mathrm{~A}$ further advantage of involving academics in the article selection process is that student editors can have the confidence that the content they are preparing for publication is already of a high standard, generating a working presumption that their interventions will be 'light touch' in nature. This task is not without challenge, for as Stephen Guest's introduction to the inaugural edition of the UCL Jurisprudence Review explained, responses to essay questions do not naturally make for stand-alone articles. ${ }^{77}$ Student editors are often responsible for shaping coursework submissions by adapting introductory material to integrate the question at issue into the text.

The homogeneity of US law review teams as an "academic elite" has also drawn criticism as it limits the transformative potential of this collaborative learning experience. The student-led model does not necessarily overcome the risks of elitism, with an editorial in one of the new wave reviews noting how student editors were 'handpicked from a mountain of applicants'. ${ }^{78}$ The NELR editorial team, however, has taken on as many applicants as possible, combining undergraduate students of different levels of experience and taught and research postgraduates. This composition gives undergraduate students the opportunity to learn from the experience of the postgraduate students. It also brings together different elements of the law school's community of learning which might otherwise have little contact with each other. It should be noted that the nature of cooperation between undergraduate and postgraduate law students varies across the new wave of student-led law reviews, with the

\footnotetext{
${ }^{75}$ J. Lindgren, 'Student Editing: Using Education to move beyond Struggle' (1994) 70 Chicago-Kent LRev 95, p.98.

${ }^{76}$ K.V. Foehrkolb and M.A. De Simone Jr., 'Debunking the Myths Surrounding Student Scholarly Writing' (2014) 74 Maryland LRev. 169, p.197.

${ }^{77}$ See supra n.60, p.viii.

78 supra n.4, p.xii.
} 
Edinburgh Student Law Review, for example, maintaining that it is 'completely managed, edited and contributed to by students' with $\mathrm{PhD}$ students exclusively operating the publication's peer-review selection process. ${ }^{79}$

\section{The Pedagogic Value of Student-Led Law Reviews}

The NELR has three core pedagogic aims which it shares with UK's other student-led law reviews. The first aim is to provide training and experience for the editorial team itself. Leo Martinez has suggested that in the US the 'use of law reviews is a means to a pedagogical end - the training of students in careful ... reading of minutia' ${ }^{80}$ This analysis conceives of law review activity as the mechanical checking of footnotes, spelling, grammar and the formatting of content. But all of this activity is peripheral to the 'development of new skills such as editing and online publishing, ${ }^{81}$ Law reviews give an outlet for the creativity of the student editorial team and their ideas about the shape of legal education outwith the structure of their courses. In line with the ambitions of US law reviews, they seek to enhance the teamworking and production skills of the student editors:

The law review is one of the few places in the law school where students whose abilities inspire and enable them to go beyond the minimum prescribed work not only have the opportunity to probe deeper into the law (and put to actual use the analytical, research, and persuasive tools that they have been amassing) but also are able to see that work come to fruition as a published volume. ${ }^{82}$

Karl Llewellyn lauded 'the group-spirit, the group work, the group-discussion, about law, about law school, about review problems, about class problems, which are the essence of the law review' ${ }^{83}$ Even in the context of undergraduate-focused legal education, law reviews encourage students to shape their learning environment and provide the opportunity to exchange ideas and experiment.

Successive NELR editorial teams have treated the publication as the beginning, rather than the end, of their educational experimentation. Alongside managing the periodical they

\footnotetext{
${ }^{79}$ B. Holligan \& C. Jayatilake, 'Editorial' (2013) 2 Edinburgh SLR vii, p.vii.

${ }^{80}$ L.P. Martinez, 'Babies, Bathwater, and Law Reviews' (1995) 47 Stan LRev 1139, p.1140.

${ }^{81}$ Biggs, supra n.70, p.i.

82 S.M. Martin, 'The Law Review Citadel: Rodell Revisited' (1986) 71 Iowa LRev 1093, p.1101.

${ }^{83}$ K.N. Llewellyn, The Bramble Bush (Oceana Publications, 1930) p.161.
} 
have developed a companion blog, North East Law Talk, ${ }^{84}$ to provide a forum for both students and academics to exchange ideas on topical issues and as a vehicle for writing competitions which generate interest amongst the student body. The ephemeral nature of legal blogging, by comparison to full-length review submissions, allows student authors to experiment and hone their analysis of current legal issues and gives editors the opportunity to set quality thresholds and actively shape submissions. Building upon their training in manuscript editing NELR editorial teams have also organised seminars on legal writing, legal blogging and legal careers to share the insights they have gained in their roles. Such events foster the sort of collaborative learning culture which has been shown to promote academic achievement at undergraduate level. ${ }^{85}$ John Noonan has argued, in the US context, that 'to enter the heart of discipline such as law, one has to exchange ideas ... argue for ideas, and point out to others the logical implications, the missing factual foundations, and the underlying assumptions of their ideas'. ${ }^{86}$ Participation in law reviews provides students with a unique opportunity to engage with legal research, writing and editing ${ }^{87}$ and emphasises the importance of attention to detail. ${ }^{88}$ In encouraging conceptual understanding and allowing students to shape their learning environment, law reviews engage students' 'intrinsic' 89 motivations for legal study. They also harnesses powerful extrinsic drivers related to future employment prospects, a point articulated by Lord Hope in his support for the Edinburgh SLR; '[a] reference to editorship of this Review will not escape notice if it appears on the cV of someone who is applying to be a judicial assistant to the UK Supreme Court' ${ }^{90}$

The second aim of law reviews is to encourage students to engage with advanced source material and theoretical concepts and to thereby hone their own analytical skills. ${ }^{91}$ In a paean to 'valid and valuable' undergraduate research Jane Bryan recounts that enabling students to take on such activity through the Warwick SLR gave them 'the opportunity to experience the thrill of finding the new and the satisfaction of seeing a project from conception to completion'. ${ }^{92}$ Law reviews do not encourage students towards such higherlevel engagement simply by providing a "pat on the back" for those whose work is selected

\footnotetext{
${ }^{84}$ Available at: https://blogs.ncl.ac.uk/nelr/ (accessed 18 Oct 2015).

${ }^{85}$ P.G. Montana, 'Peer Review Across the Curriculum' (2013) 91 Oregon LRev 783, p.789.

${ }^{86}$ J.T. Noonan, "Law Reviews" (1995) 47 Stanford LRev 1117, p.1118.

87 J.W. Harper, 'Why Student-Run Law Reviews?' (1998) 82 Minnesota LRev 1261, p.1272.

${ }^{88}$ N.H. Saunders, 'Student-Edited Law Reviews: Reflections and Responses of an Inmate' (2000) 49 Duke LJ 1663, p. 1670.

${ }^{89}$ J. Biggs, Teaching for Quality Learning at University (Open UP, 2002) p.191.

${ }^{90}$ D. Hope, 'Foreword' (2009) 1 Edinburgh SLR v, p.v.

${ }^{91}$ See O. Ben-Dor, 'Forward' (2014) 4 Southampton SLR i, p.i.

92 J. Bryan, 'Foreword' (2012) 2 Warwick SLR i, p.i.
} 
(although many students will undoubtedly be attracted to publishing their work by the extrinsic benefit of being able to highlight the achievement in their curriculum vitae ${ }^{93}$ ). As Llewellyn noted the reworking process associated with law review publication requires student editors 'to diagnose a problem, to size it up, to locate relevant material, to analyze it, to reject the worse of what he finds in favor of the better (and that is hard, that scrapping of hard labor) - and then to put together again; to criticise and then to build' ${ }^{94}$ In the student-led model student authors can be brought into this process by giving them the opportunity to rework their submission in light of academic feedback. This reworking process 'closes the feedback loop' initiated by assessed coursework by encouraging students to engage with academic feedback and regard it as a means by which their work can be improved. ${ }^{95}$ In the NELR context, even students who have completed their dissertations, and graduated, have been eager to take this opportunity to improve on their work before turning it over to the editorial team. As such, the law review takes its place alongside, and enhances, the range of other extra-curricular activities that UK law schools increasingly offer for their student cohorts. As Amandine Garde noted on the inauguration of the ULLR:

Our students are engaged in schemes that promote pro-bono work and provide direct advice to those in need of help though our award-winning Law Clinic. They reach out to local communities through our Street Law project and they volunteer their services to local Citizens Advice Bureaux. It is my hope that the University of Liverpool Law Review will highlight the academic discipline that empowers our students to engage so enthusiastically in all these activities. ${ }^{96}$

As more student-led law reviews emerge, prospective undergraduates will increasingly expect to be able to play a role in such publications and reap the associated benefits at their chosen law school.

Third, the publication of high-quality undergraduate and taught postgraduate research allows the wider community of law students to benchmark their own performance against the published contributions. For Scott Martin, the traditional law school curriculum provides

\footnotetext{
93 supra $\mathrm{n} .87, \mathrm{p} .1273$.

${ }^{94}$ supra n.83, p. 161.

${ }^{95}$ Under David Boud's account of the feedback loop, '[u]nless students are able to use the feedback to produce improved work, through for example, re-doing the same assignment, neither they nor those giving the feedback will know that it has been effective'. D. Boud, 'Sustainable Assessment: Rethinking Assessment for the Learning Society’ (2000) 22 SCE 151, p.158.

96 A. Garde, 'Foreword' (2015) 1 ULLR iv, p.iv.
} 
little training in the techniques of legal research and writing, ${ }^{97}$ and law reviews potentially 'do an excellent job of making up for these omissions'. ${ }^{98}$ In common with peer-review marking exercises, student-led law reviews give the student body at large the opportunity to read other students' work and to evaluate their own performance against it. At a time when the transition between secondary and higher education is increasingly becoming an issue of sector-wide concern, ${ }^{99}$ and "information saturation" 100 is a frequent complaint by students, particularly with regard to the vexed issue of how to improve performance, a student-led law review can be a powerful tool for cutting through these problems. As Cassandra Hill explains, 'students open their minds to other possibilities when they see how different writers approach and analyse the same problem or task'. ${ }^{101}$ In publishing meritorious student work and making it available on a reliable open-access platform, a review gives other students (both within the institution and beyond) a more penetrating insight into the standards of legal writing expected in the highest mark bracket than can be achieved from desiccated mark schemes or guidance documents. A further benefit is that publishing the best responses to previous years' coursework questions pushes academics to keep refreshing their essay topics. A review can therefore promote 'a Law School community where staff and students exchange ideas outside as well as inside the curriculum'. ${ }^{102}$

\section{The (Potential) Contribution of Student-Led Law Reviews to Legal Scholarship}

As the primary focus of most of the new-wave of UK student-led law reviews is the publication of student work, much of the focus of our account has been upon the pedagogic benefits of such publications. This is not to underestimate the possible contribution of student-led law reviews to legal scholarship, but to recognise that they have yet to achieve their potential in this regard. The open-access and not-for-profit nature of the student-led law review format means that these publications can reach a wide audience on the basis of low production costs. Whilst the subject-specific inexperience of the student editorial team can impact on a publication's content and the standard of copy editing, the former problem can be

\footnotetext{
${ }^{97}$ supra $\mathrm{n} .83$, p.1099.

${ }^{9}$ Ibid., p. 1100.

${ }^{99}$ See S. Kift, K. Nelson \& J. Clarke, 'Transition pedagogy: a third generation approach to FYE' (2010) 1 IJFYHE 1.

${ }^{100}$ supra n.1, p.19.

${ }^{101}$ C.L. Hill, 'Peer editing: A comprehensive pedagogical approach to maximize assessment opportunities, integrate collaborative learning, and achieve desired outcomes' (2011) 11 Nevada LJ 667, p.673.

102 supra n.69, p.viii.
} 
alleviated through management of content selection by academic staff, whilst the latter can be addressed through editor training sessions. What student editorial teams lack in terms of subject knowledge is, moreover, counter-balanced by the ability of law reviews to draw upon the technical expertise of 'students who have grown up with the Internet', ${ }^{103}$ enabling these publications to adapt to new technology faster than traditional peer-reviewed legal journals by experimenting with features such as companion blogs, micro blogs or video blogs.

The NELR's creation built upon Newcastle University's track record with openaccess legal scholarship. Open-access, although a term subject to multiple interpretations, 'implies that authors should grant free access and rights to use published works, subject only to proper attribution of authorship' ${ }^{104}$ This approach to academic publication is internet dependent. In the mid-1990s, when the open-access movement was in its infancy, ${ }^{105}$ the Web Journal of Current Legal Issues was created following discussions amongst Newcastle staff and hosted on Newcastle University servers with the following goals:

(a) to provide authors the opportunity to make timely comment upon legal matters of current importance and (b) to provide readers with a free source of timely and useful legal writing. Much later such objects came to be described as "Open Access" (OA) but in 1995 that was not a term in common use. ... In modern jargon the Journal is an example of gold gratis OA. ${ }^{106}$

The Web Journal embodied the Finch Report's account of a first-generation open-access journal, 'founded by individual scholars on tailor-made platforms, often with a business model based on voluntary labour and the use of a university's web server free of charge'. ${ }^{107}$ The two great advantages of such publications are their low cost base and the ease with which published articles can discovered by interested readers using search engines. ${ }^{108}$

When the Web Journal and its archive migrated to the servers of Queen's University Belfast in 2013, becoming the European Journal of Current Legal Issues shortly thereafter, the NELR was not seen purely as a teaching tool but as a means of maintaining Newcastle

\footnotetext{
103 supra n.23, p.637.

${ }^{104}$ See J. Finch, 'Accessibility, sustainability, excellence: how to expand access to research publications' (2012) para.3.34, available at: http://www.researchinfonet.org/wp-content/uploads/2012/06/Finch-Group-reportFINAL-VERSION.pdf.

${ }^{105}$ Ibid., para.3.33.

${ }^{106}$ B. Grant, 'A History of the Web Journal of Current Legal Issues' (2013) 19 Web JCLI.

107 supra n.104, para.3.38.

108 supra n.1, p.23.
} 
Law School's connection with open-access publishing at a time when UK academic publishing was undergoing upheaval. The Coalition Government's acceptance of the Finch Report's key recommendations that publically-funded research should be publically available without pay-wall restrictions ${ }^{109}$ increased the attractiveness of in-house open-access publishing. ${ }^{110}$ Moreover, as the Cambridge student periodicals exemplified, a law school can rapidly transform a student-led publication into a student-administered one. The shift from the Cambridge SLR to the CJICL involved a move from a model focused upon undergraduate content generated within the parent institution to the double-blind peer review of unsolicited academic submissions. The extensive involvement of research postgraduates in the CJICL's editorial team allowed Cambridge (and other institutions like UCL which have similarly revamped the publications they host) to use the publication to develop their research skills. This responds to the need for law schools, under the REF framework, to take active steps to enhance their research environment. Indeed, following UCL's performance in the 2014 REF, the Head of School Hazel Genn recognised the contribution of UCL's student-administered journal 'to a research environment that is recognised by the Research Excellence Framework as being second to none'. ${ }^{111}$

The adoption by new student-led law reviews of open-access publishing, combined with their low running costs and the commitment of student editorial teams, provides a basis for a distinctive contribution to legal scholarship. The challenge, however, remains finding an approach which enhances the contribution of student law reviews to legal scholarship without side-lining their educational mission. Whereas most US law reviews maintain distinct articles and comments sections for academic- and student-generated content as a matter of routine, no UK journal has yet combined these forms of content in a single output. The long-standing reticence surrounding student involvement in legal publishing continues to inhibit the emergence of such publications. This barrier is, however, largely an issue of perception; that a publication maintains a section for student-generated content does not of itself undermine the rigorousness of a separate peer-reviewed section for academic content. Moreover, notwithstanding the failure of mixed-content law reviews to emerge to date in UK legal

\footnotetext{
${ }^{109}$ The Government maintained that 'a clear policy direction should be set towards support for publication in open access or hybrid journals ... as the main vehicle for the publication of research'; D. Willetts, 'Government Response to the Finch Group Report: "Accessibility, Sustainability, Excellence: How to Expand Access to Research Publications" (16 Jul 2012) p.2. Available at: https://www.gov.uk/government/uploads/system/uploads/attachment_data/file/32493/12-975-letter-governmentresponse-to-finch-report-research-publications.pdf (accessed 12 Oct 2015).

${ }^{110}$ For some of the advantages over traditional journals, see R. Darley, D. Reynolds \& C. Wickham, Open Access Journals in Humanities and Social Science (British Academy, 2014) pp.68-76.

${ }^{111}$ H. Genn, 'Foreword' (2015) 4 UCLJLJ v, p.v.
} 
academia, innovative features common in student-led publications (such as blogs and twitter feeds) are increasingly being adopted by mainstream legal journals.

At a time when the REF prioritises certain forms of academic scholarship, studentgenerated content could populate sections of law reviews which have consequently become stale. Case notes, for example, were historically an important tool by which UK legal academics sought to actively influence future judicial practice, ${ }^{112}$ but are now a low priority for many UK legal academics given the limited value attributed to such outputs under the REF framework. ${ }^{113}$ Law reviews which are willing to accept case notes prepared by student authors encourage students to engage in the analysis of case law and preserve an important form of academic interaction with jurisprudence. Quality control could be maintained by adopting a case note exercise as a structured assessment in a legal skills module and selecting contributions on the basis of the assessment results. Similarly, student contributions to book reviews sections could both reinvigorate the flagging practice of reviewing new publications and, by encouraging students to engage with entire academic monographs, and contextualise them within existing literature, could provide an advanced element of research skills training. Student administration could enable the flourishing of institutional periodicals throughout the UK on an online open-access model by bringing a greater level of technical expertise to such publications than many legal academics possess, and through large voluntary editorial teams being able to make a greater time commitment than individual academics could sustain.

\section{Conclusion}

In the UK the burgeoning interest in student-led law reviews since 2009 has generated an expanding range of subtly-distinct periodicals. But whilst the pedagogic benefits of lawreview activity evidently can, through the active support of academic staff, extend beyond 'displays of footnote finesse ${ }^{114}$ by student editors, the student-led law review's place in UK legal education remains uncertain. Some publications, such as the Kent SLR, were explicitly established as vehicles for advancing the ethos of the parent law school by showing 'the legal

\footnotetext{
${ }^{112}$ See N. Duxbury, Frederick Pollock and the English Juristic Tradition (OUP: 2004) 316-322.

${ }^{113}$ The 2014 REF Subpanel for Law noted that case commentaries continued to be submitted as REF outputs, but they make up a vanishingly small percentage of the overall outputs submitted, far outweighed by monographs, edited collection chapters and journal articles. See Research Excellence Framework 2014: Overview Report by Main Panel $C$ and Sub-panels 16 to 26 (January 2015), 70. Available at: http://www.ref.ac.uk/media/ref/content/expanel/member/Main\%20Pane1\%20C\%20overview\%20report.pdf (accessed 12 Oct 2015).

${ }^{114}$ supra $\mathrm{n} .19$, pp.648-649.
} 
community the unique, diverse and intellectual stimulation that the University of Kent provides, which sets us apart from the vast majority of black letter institutions across the country'. ${ }^{115}$ In an increasingly competitive student recruitment environment, it should be unsurprising that law schools are attracted to law reviews as a 'showcase' for their institutional vitality, to be displayed at open days and events and trumpeted as a feature of their research environment. ${ }^{116}$ Should student-led law reviews be more widely recognised as a cost-effective means of delivering these goals, they are likely to become even more widespread in the near future.

As adherence to the student-led model increases there is the chance that a tipping point will be reached. Potential students could come to expect that an active periodical will be one of the extra-curricular activities supported by their shortlisted law schools. Under this pressure student-edited law reviews could quickly become as ubiquitous a feature of UK legal education as they currently are within the US. But this tipping point could also be a moment of danger for law reviews. The US-model law review was profoundly shaped by a vision of these publications' place within legal education and academic discourse advanced by a small number of early-adopter institutions. The tenure of student editorial teams is short, and as Posner has noted with regard to US reviews, this means that the 'planning horizon is foreshortened'. ${ }^{117}$ In such an environment innovation is stifled and new law reviews will become increasingly likely to mirror successful existing publications. The range of approaches to student involvement in institutional law reviews currently operating in the UK could give way to a series of homogenous offerings. Institutions which have pulled away from journals publishing undergraduate content, including Cambridge and UCL, might well find themselves obliged to reanimate such periodicals. But such a loss of diversity is by no means inevitable. Our overview of the NELR case study has demonstrated just one approach by which the student-led review model can make a substantial contribution to the learning experience of students. With further nurturing they can also make a more extensive contribution to academic discourse upon law. The active involvement of academic staff in guiding new UK law reviews provides for an institutional memory and extends the planning window beyond the immediate interests of particular editorial teams. Shaped by this cooperation, the time of UK student-edited law reviews could finally be at hand.

\footnotetext{
115 supra $\mathrm{n} .70, \mathrm{p} .1$.

116 supra $\mathrm{n} .4$, p.i.

${ }^{117}$ supra n.27, p.1132.
} 